\title{
O ESPIRITISMO EM PONTA GROSSA - PR: PERSPECTIVAS DE UM ESPAÇO DO ALÉM E PARA UM ALÉM DO ESPAÇO'.
}

\author{
Marino Luís M. Godoy²
}

$\mathrm{Na}$ geografia da religião, pode-se entender o espaço como palco de expressões culturais resultando das manifestações de crenças e valores. Este tipo de espaço contextualiza concreta e subjetivamente o indivíduo religioso em determinados meios sociais através de suas particulares percepções e expressões de vivência ficando também embutido em suas concepções específicas do mundo. Compreendendo-se o espaço geográfico como passível dessas distintas interpretações, a pesquisa pretende analisar a Doutrina Espírita e o seu desenvolvimento na cidade de Ponta Grossa - PR. Intenta-se avaliar a relevância sócio-cultural do Espiritismo como uma manifestação da vida urbana. O arcabouço teórico-prático da Doutrina Espírita sustenta-se em três pilares de complexa conciliação, da religiosidade, da filosofia e da ciência e, deste modo, abrange uma percepção do mundo além de uma simples religião e de uma interpretação meramente científica. Por isso, necessita-se uma abordagem conceitual que estabeleça uma relação entre a Geografia e o elemento religioso do espaço. Para tanto, consideram-se três instâncias de análise principais com fins a compreender o espaço do fenômeno espírita, a entender: a Espacialidade Narrativa, a qual busca compreender as relações estabelecidas entre o plano terreno e o espiritual, esta uma concepção geográfica da própria doutrina; a Espacialidade Prática, evidenciando as práticas e relações estabelecidas entre os espíritas em diferentes lugares, esta uma concepção da geografia social; e a Espacialidade Institucional que visa explicitar a geograficidade da organização espírita e entender a lógica de sua estrutura e distribuição, esta parte da geografia política. Portanto, compreender o espaço através da visão espírita e sua interação social abre um diálogo entre o sistema de valores da própria geografia para com a doutrina do Espiritismo, considerando sério seu caráter metafísico e sua ideologia.

PALAVRAS-CHAVE: geografia da religião; espaço religioso; espiritismo; Ponta Grossa - PR.

\footnotetext{
${ }^{1}$ Orientador: Prof. Dr. Wolf-Dietrich G. J. Sahr

2 Mestrando em Geografia (UFPR) - e-mail: marinogodoy@hotmail.com
} 